\title{
SMART CARD READER AND THE 2015 GENERAL ELECTIONS IN NIGERIA
}

\author{
Emmanuel Adeniran Alebiosu \\ Emmanuel Adeniran Alebiosu is a lecturer in the \\ Department of Political Science at Federal University Wukari, Nigeria \\ email: alebiosuemma@gmail.com
}

\begin{abstract}
A central issue in the 2015 general elections in Nigeria was the use of the smart card reader, which was a critical component in the election. It was used for the first time in the electoral process of Nigeria and it remains one of the greatest technological innovations of the 2015 general elections. The smart card reader is a technological device set up to authenticate and verify, on election day, a permanent voter card issued by the Independent National Electoral Commission. The fundamental basis for deploying the technological device was to ensure a credible, transparent, free and fair election and thereby to deepen Nigeria's democracy. However, the use of the card reader generated debate among election stakeholders before, during and after the 2015 general elections. One such debate was the legality of the use of the device. In this paper I examine the debate and the role of the card reader in the elections. I also consider the challenges and impact of the card reader on the election. Considering the massive electoral fraud witnessed in general elections since Nigeria's independence, I conclude that the smart card reader should be used for future elections. General elections in Nigeria should continue to be technologically managed.
\end{abstract}

Keywords: democracy, electoral fraud, permanent voter card, election technology

\section{INTRODUCTION}

Nnoli (1990, p. 2) defines election as the manner of choice agreed on by a group of people which enables them to select one person or a few people out of many to occupy one or more positions of authority. Indeed, elections encapsulate the mediating institutional and psychological processes and anchors for adult citizens to express, in an organised and routine manner, their choice among those who 
seek public political office (Jinadu 2005, p. 3). Elections help to determine periodic tests of parties' and candidates' acceptance and popularity. They also confer legitimacy on public office-holders, and subject public office-holders and political parties to periodic assessment. By so doing, elections enhance accountability and good governance (Okolie 2005, p. 436).

Elections are a critical component of any democratic society. As such, Nigeria's return to democratic rule and engagement with the democratic process led to the conduct of its general elections in 1999, 2003, 2007, 2011 and 2015. General elections are elections conducted in the federation at large for federal and state elective positions (The Electoral Institute 2014).

The 2015 general election appears to have been the most keenly contested in the history of elections in Nigeria. It was the first time about four major opposition parties came together to form a very strong party, the All Progressive Congress (APC) in order to challenge the dominance of the ruling party, the Peoples Democratic Party (PDP) in the polity. According to Omotola (2013, p. 172) the election became the only game in town, shaping and reshaping public discourse and political actions.

Prior to the 2015 general elections, a number of technologically based reforms were embarked upon by the new leadership of the Independent National Electoral Commission (INEC), headed by Prof Attairu Jega. These included the biometric register of voters and an advanced fingerprint identification system. INEC is the election management body empowered by the 1999 Constitution (as amended) of the Federal Republic of Nigeria to organise, undertake and supervise all elections in Nigeria.

The use of biometrics in African elections is on the rise. No fewer than 25 sub-Saharan African countries (including Sierra-Leone, Democratic Republic of Congo, Zambia, Malawi, Rwanda, Senegal, Somaliland, Mali, Togo and Ghana) have already held elections employing a biometric voter register (Piccolino 2015). In Nigeria, the automated fingerprint identification system was used in the 2011 general elections to eliminate multiple registrations from the voter list, but it was not capable of verifying the identity of voters at the polling stations (Piccolino 2015). In view of this, INEC adopted the use of the permanent voter card (PVC) system and introduced smart card reader technology, a device used to scan PVCs to verify the identity of voters at the polling booth. The smart card reader was one of the greatest innovations of biometric verification technology and a controversial but crucial aspect of the 2015 general elections in Nigeria. Other African countries, including Ghana, Kenya and Somaliland, had adopted biometric verification technology. The technology is particularly useful in settings where governments have not previously established reliable or complete paper-based identification systems for their populations (Gelb \& Decker 2012).

Concerned about the massive electoral fraud witnessed in past general 
elections in Nigeria, INEC deployment of the card reader during the 2015 general elections was aimed at ensuring a credible, transparent, free and fair election. This would deepen Nigeria's electoral democracy. However, the use of the electronic device in the 2015 general elections generated debate among election stakeholders at the time of the elections. In this paper I focus mainly on the role of the card reader in the 2015 general elections and the future of the card reader, but I also examine other selected issues related to the elections.

\section{SELECTED ISSUES IN THE 2015 GENERAL ELECTIONS IN NIGERIA}

The 2015 general election was the closest electoral contest since the country's post-1999 transition to multi-party democracy (International Republican Institute 2015). The election was the most politically engaged in the history of electoral democracy in Nigeria. Huge resources were used for the elections, including 120 billion naira expended by INEC, with election staff numbering 750000 ad-hoc members and more than 360000 security personnel. The presidential election was contested by fourteen candidates from different political parties. The candidates from the PDP, Dr Goodluck Jonathan, and the APC, General Muhammadu Buhari, were the major contenders.

The 2015 general election was the fifth general election since Nigeria resumed democratic rule in 1999. Nigerians went into the general elections with renewed determination to exercise their voting rights and stood stoutly to monitor and protect their votes with anything and everything (Momodu 2015). The election was bedevilled with issues that almost denied Nigerians the opportunity of voting their representatives into government for another four years. These issues almost affected the integrity, quality and management of the election. Indeed, quality election management is crucial to sustaining democracy. If the citizenry does not believe in the fairness, accuracy, openness and basic integrity of an electoral process, the very basis of democratic society can be threatened. This implies that public faith in the integrity of the election system is a cornerstone of democratic government (Alvarez \& Hall 2008, p. 134). In view of this principle, the International Foundation for Electoral Systems (2015) argued that a legitimate electoral process and public confidence in democratic governance depend on both the actual and perceived integrity of an election. Some issues in the 2015 general election were security threats and election postponement, the expiration of tenure of the INEC Chairman, and the introduction of technology.

\section{Security threats and election postponement}

The 2015 general election was conducted amidst security threats and challenges, especially the Boko Haram insurgency. The Boko Haram insurgents had engaged 
in kidnapping, massive killings and wanton destruction of property. The terrorist group had also captured territories in Nigeria, which was effectively under their control, and the insurgents had threatened to disrupt the 2015 general elections. Against this background, the 2015 election which was scheduled to be held on 14 and 28 February 2015 was postponed by INEC to 28 March and 11 April 2015. The National Security Adviser, Col. (Rtd.) Sambo Dasuki, stated that the general elections scheduled for February 2015 could not be guaranteed in view of the security threats and challenges across the country. According to Dasuki this was because most men in the Nigerian Army were engaged in Nigeria's north-east, confronting Boko Haram insurgents. He contended that six weeks' postponement of the general elections would enable the armed forces to subdue and reclaim the territories that were effectively under the control of Boko Haram.

The postponement was received with mixed feelings. Some individuals, groups and political parties - especially the PDP - supported the decision. Supporters of the postponement were of the view that it would guarantee peace and security across the country. Other individuals, groups and political parties - particularly the APC - outright rejected the rescheduling of the 2015 general election. Some parties, including APC, accused the PDP-led Federal Government of deliberately allowing insurgency in the north-east, an opposition stronghold, to fester so the party could cash in on the crisis and be re-elected. Adichie (2015) has argued that the postponement was a flailing act of desperation by Dr Goodluck Jonathan not to lose the election. Jonathan was the Nigerian President between 2011 and 2015 and he was the PDP's presidential candidate in the 2015 general elections. Similarly, Chief Olusegun Obasanjo, former Nigerian President (19992007), described the date shift as a grand plan by the PDP presidential candidate to win the election at all costs. Nwankwo (cited in Kendhammer 2015) believed that the intention behind the rescheduling was to undermine the democratic process and to stop support growing for APC in the country.

It seems INEC was persuaded by the security apparatus of the Nigerian state to reschedule the 2015 general elections, and this singular act embarrassed Nigeria and Nigerians. Indeed, the postponement of the election appears almost to erode public credibility and confidence in the elections. Billions of naira from public funds had already been expended towards preparing for the election despite Boko Haram's annexation of territories. Considering the security threats and challenges, how could people, materials and logistical arrangements be distributed and managed effectively for a violence-free election during and after the poll with its changed dates?

The contention by some stakeholders in the 2015 elections that territories captured by the terror group could have been excluded from the poll appears to me as irrational. The question would be - are these groups of people not Nigerians? 
Had these categories of people been excluded in the 2015 elections, it would have amounted to a breach of their democratic and fundamental human rights. This may have led to legal actions that would have impacted negatively on the general elections. Some stakeholders were quick to mention that countries such as Afghanistan and Iraq have successfully held elections although they were in a state of war. However, this statement does not accurately reflect the true situation in these countries. The security of an election is unique to the circumstances in which it is conducted. The stakes for any given election are different - even if elections are held periodically in the same country - owing to the changing forces that shape the national interest and corresponding political agenda (Dunne 2006). Neither Afghanistan nor Iraq had any of their territories under the effective control of the terrorist groups that operated in these countries when their general elections were conducted in April 2014. The terrorist groups were Taliban in Afghanistan, and Islamic State of Iraq and Levant in Iraq. The terror groups in these countries usually embarked on suicide bombings and attacks. In fact, within 48 hours of their respective general elections, security personnel and civilians' lives and properties were destroyed.

Security is a critical component of electoral democracy. Indeed, good security is one of the requirements to achieve credible and transparent elections. Ensuring a fairly secure environment for voters and sensitive materials on election day in all areas of the country is a necessary condition for holding democratic elections. The absence of basic security measures will jeopardise, if not severely harm, the acceptability of the results (López-Pintor 2010, p. 15).

To ensure the integrity of the electoral process, various security measures need to be instituted during all phases of an election (International Foundation for Electoral Systems 2015). Indeed, the assurance of equitable security during an electoral process is essential to retaining the participants' confidence and commitment to an election. Consequently, security is integral to the goal of an electoral process (Dunne 2006). In view of this, INEC could not have continued with the 2015 general elections if the security agencies could not guarantee the safety of lives and properties before, during and after the elections. However, this fact calls into question the primary responsibility of government - which is to provide security and welfare for its citizens as enshrined in section 14 (b) of the 1999 Constitution (as amended) of the Federal Republic of Nigeria.

Furthermore, the 2015 general election rescheduling was within the constitutionally stipulated period for the conduct of the elections by INEC. The 1999 Constitution (as amended) stipulates that elections for the offices of president and vice-president, governors and deputy governors, and members of the National Assembly and Houses of Assembly shall be held not earlier than 150 days and not later than 30 days before the expiration of the term of office of the last holder. 
In addition, section 25 of the Electoral Act (as amended) empowers INEC to set a date not earlier than 150 days but not later than 30 days before the expiration of the term of office of the last holder.

Section 26 of the Electoral Act, 2010 (as amended) empowers INEC to postpone an election where there is reason to believe that a serious breach of the peace would occur if the election was held on a said date. Therefore, the postponement of elections is within the purview of INEC's powers following security concerns raised by the National Security Advisor (Policy \& Legal Advocacy Centre 2015a). It is therefore my opinion that the postponement of the 2015 general elections was not in breach of any law in Nigeria. The rescheduling of the election was in order considering that 29 May 2015 (63 days after 28 March 2015) was the handover date.

Another justification was that the Nigerian armed forces were able to reclaim territories during the period of postponement, and subsequently went on to integrally involve the military under a special arrangement in the 2015 general elections. However, the deployment of the military in the 2015 elections generated controversy among stakeholders in the election - to the extent that court judgment was delivered on the issue. The human rights activist Falana (cited in Premium Times 2015) argued that military involvement in providing security for the elections was unconstitutional. He maintained that INEC was wrong to insist that only the military could guarantee security during the 2015 general elections. He noted that the obligation to provide security and maintain law and order during elections rests on the police and not the military.

The deployment of the military in the 2015 general elections became an issue in view of the previous massive deployment of the military in the Ekiti and Osun States governorship elections of 2014. In those earlier elections, some political parties accused the military of playing out a script in the elections. However, the military were not directly involved in the 2015 general elections and the role of the military in the election was very limited. No military officer was posted to any polling booth. They were deployed to major roads for security checks to prevent security breaches during and after the elections.

\section{Expiration of tenure}

While the issues of security, deployment of the military and postponement of the 2015 general elections were still generating controversy among election stakeholders, the sudden debate about the expiration of tenure of the INEC chairman - and subsequent calls for his removal - further compounded the fear, in some quarters, that the 2015 general elections might not be held if they were rescheduled. There was speculation that the INEC chairman might be asked to proceed on terminal leave in March 2015 before the expiration of his tenure in 
June 2015. The PDP-led federal government was accused of plotting this inordinate agenda. Various individuals and groups called for the removal of the INEC head (Ebhomele 2015). They included the Movement for the Actualization of the Sovereign State of Biafra (MASSOB), the Oodua People's Congress (OPC) and the Afenifere Renewal Group (ARG), as well as some former militants in Niger Delta and even some state governors - such as Ekiti State Governor, Ayo Fayose (Ebhomele 2015). Other groups and individuals kicked against his removal.

INEC is a body established under law by virtue of section 153 of the 1999 Constitution (as amended) of Nigeria. Furthermore, section 157 states that for the removal of an INEC boss, a two-thirds majority of the Senate must support the request by the president. Such removal must, however, be the result of the chairman's inability (whether arising from infirmity of mind or body or any other cause) to discharge the functions of the INEC office, or misconduct. Has the chairman of INEC been declared medically unfit? Has the INEC boss failed to discharge his duties for any reason? Has he engaged in any misconduct while carrying out his responsibilities?

INEC's previous chairman, Prof Maurice Iwu, was removed illegally in a manner that was undemocratic and was not challenged. This fact calls into question the practice of rule of law and constitutionalism in Nigeria's democratic process. The hullabaloo about removing the INEC boss appears to me to have been an attempt to coerce him to rescind some of the reforms he embarked on in Nigeria's electoral democracy in preparation for the 2015 general elections.

Prof Jega is the first Nigerian to have conducted two consecutive general elections (2011 and 2015) in the country. His appointment came at a time when the democratisation process was bedevilled by badly conducted elections that left Nigerians frustrated and questioning the value and validity of electoral democracy (Jega 2014, p. 4). To address this ugly situation, Prof Jega started a series of reforms to deepen Nigeria's electoral democracy. Chief among these was the introduction of the smart card reader for the 2015 general elections.

\section{Smart card reader: The real issue in the 2015 general elections}

The smart card reader was the most contentious issue in the 2015 general elections. The smart card reader was a critical component in these elections and it was being used for the first time in Nigeria's electoral process. The card reader remains one of the greatest innovative technologies from the 2015 general elections.

Past elections in Nigeria had witnessed the desperate bid for political power by some stakeholders with vested interests in Nigeria's electoral process. Certain stakeholders engaged in all forms of electoral malpractices - including multiple voting, impersonation, manipulation and falsification of results - which led to 
legal action, electoral conflict and violence. Electoral malpractices make citizens lose confidence in the electoral process; and lack of confidence by citizenry in the democratic process is an impediment to deepening electoral democracy. If the citizenry does not believe in the fairness, accuracy, openness and basic integrity of the election process, the very basis of any democratic society might be threatened (Alvarez \& Hall 2008, p. 134).

According to López-Pintor (2010, p. 9), electoral fraud has even more serious political implications in that it allows a party or candidate to take over public positions contrary to the popular will. This undermines the democratic process and usually leads to electoral violence, insecurity and political instability. The governments of Cote d'Ivoire, Peru and Serbia all collapsed in 2000 as a result of popular rebellions against fraudulent elections. Similarly, the so-called 'Orange Revolution' in Ukraine in 2004 led to presidential elections being completely reheld after extensive fraud was demonstrated (López-Pintor 2010, p. 5).

In view of the negative effects of electoral malpractice, global attention is now focusing on how to mitigate this undemocratic behaviour and improve the electoral process. One strategy to combat electoral malpractice is the introduction of information and communication technology into the electoral process. The use of technology in elections is not an end in itself but assists with various aspects of electoral administration (ACE Project n.d).

Against this background, an electronic technology-based device, the smart card reader, was introduced into the Nigerian electoral process in 2015 to help improve and deepen electoral democracy. The smart card reader is a technological device to authenticate and verify voters with PVCs. The device uses a cryptographic technology that has ultra-low power consumption, with a single core frequency of $1.2 \mathrm{GHz}$ and an Android 4.2.2. operating system (INEC 2015). The INEC card reader is designed to read information contained in the embedded chip of the permanent voter card issued by INEC to verify the authenticity of the PVC and carry out verification of the intending voter, by matching the biometrics obtained from the voter on the spot with the ones stored on the PVC (Engineering Network Team 2015). The card reader performs these functions while also keeping a tally of the total numbers of voters accredited at the polling unit and forwarding the information to a central database server over a global system for mobile (GSM) network. These features make the card reader most welcome at this point in time in the nation's electoral history (Engineering Network Team 2015).

The fundamental basis for the deployment of the technology-based device in the 2015 general elections by INEC included the following motivations:

- to prevent electoral fraud

- to allow the electorates' votes to count 
- to reduce litigation arising from elections

- to authenticate and verify voters

- to protect the integrity and credibility of the election

- to audit results from polling units across the federation

- to ensure transparency and accountability.

Other reasons included the need for statistical analysis of demographic data of voters and voting for the purposes of research and planning, to build public confidence and trust in the election, to reduce electoral conflicts, to ensure a free and fair election, and to further deepen Nigeria's electoral and democratic process.

In spite of the laudable goals and objectives of the smart card reader, it generated debate among the 2015 general election stakeholders before, during and after the polls. On the one hand, supporters of the card reader view the innovation as a deliberate effort to ensure the conduct of a free and fair election; on the other hand, there have been arguments that INEC has neither the legitimate authority nor capacity to use the card reader (Policy \& Legal Advocacy Centre 2015b).

The proponents of the device, according to Peters (2015), believe the card reader procedure can prevent or minimise rigging in the sense that there would not be multiple voting. By contrast, opponents believe that in the peculiar circumstances of the Nigerian situation, the card reader is designed to assist a certain political party to win a general election. Peters (2015) maintained that the thrust of the latter argument is that the card reader must have been programmed to assist a pre-determined winner of the election by ensuring that a certain number of votes could not be given to another party. This would ensure victory by an INEC-preferred party. There have also been mutterings about the use of a faith-based bank to transfer money to print the PVCs and the configuration of the card reader.

The allegation that card readers were designed to favour a political party has been shown as baseless, as we saw before and after the elections. None the less, this unsubstantiated sentiment led to the invasion and destruction of the APC Data Center in Lagos and the subsequent arrest of the supplier of the card readers by the Department for State Security. The Department subtly apologised to APC and later released the supplier of the card readers after no evidence was found.

The contention that a faith-based bank, JAIZ Bank, was used to pay for the supply of the card readers appears to me ridiculous. Was the transaction illegal? Was the bank not a licensed financial institution in Nigeria? Investigations showed later that another bank, First City Monument Bank, was used to make electronic payment for the supply of the card readers.

The use of the card reader in the 2015 general election was also criticised on the premise that its timing was too close for over 68 million Nigerian voters. 
Considering that the device was a relatively new technology not tested or tried in Nigeria, it was therefore argued that INEC should set aside the card reader in the 2015 general elections. This argument appears to me valid to the extent that INEC would conduct an election of such magnitude and deploy a device that has a far-reaching impact on the electoral process, but did not test the device in previous smaller by-elections to validate its effectiveness and efficiency. Moving from manual process to infusing technology in voting is a milestone that requires high efficiency. Between 2011 and 2015, INEC conducted governorship elections and by-elections in some states of the federation. Why would INEC wait for the 2015 general elections to use the card reader?

To address the issue of the card reader not being tested, INEC hurriedly conducted a pilot run with the device on 7 March 2015, just 21 days before the polls. The pilot run took place in twelve states, consisting of 225 polling units and 358 voting points, of the federation. Some card readers did not function effectively during the test run. However, INEC promised to deal with the issue. The pilot run was carried out after the general election had been rescheduled. In other words, INEC could have conducted the elections without test-running the device. This could have created a disaster for INEC.

The legality of the use of the card reader in the 2015 general elections was a crucial aspect of the debates led by critics of the card readers. To examine this issue, a careful study of Nigeria's electoral jurisprudence is needed to determine whether the use of the smart card reader by INEC falls within the confines of the law. First, as argued earlier, it is clear that INEC is a creation of the law as it is established under section 153 of the 1999 Constitution (as amended) as a Federal Executive Body. Under paragraph 15 of Part 1 of the Third Schedule to the 1999 Constitution (as amended), INEC is mandated to organise, undertake and supervise all elections in Nigeria; conduct the registration of persons qualified to vote; and prepare, maintain and revise the registration of voters for the purpose of any election (Policy \& Legal Advocacy Centre 2015b). INEC is also empowered to carry out the functions conferred upon it by virtue of the Electoral Act, 2010 (as amended).

In addition, the Policy and Legal Advocacy Centre (2015b) argued that section 118 of the 1999 Constitution (as amended) subjects the registration of voters and the conduct of elections to INEC's discretion. Similarly, section 16 of the Electoral Act, 2010 (as amended) gives power to INEC to cause to design, print and control the issuance of a voter's card to voters whose names appear on the register. Therefore, according to the Policy and Legal Advocacy Centre (2015b), INEC has express and implied powers to design means, procedures and processes that enable it to exercise the powers granted under the Constitution - which includes, for example, the use of the PVC in the 2015 general elections. 
Hence, without doubt the legal framework at the time of the 2015 general election empowered INEC to be the electoral umpire. However, sections 49 and 52 of the Electoral Act, 2010 (as amended) were subjected to legal debate with regard to the use of card readers for the 2015 general elections. To some, the deployment of card readers for the accreditation of voters at the elections tactically meant adoption of electronic voting, which the 2010 Electoral Act outlaws (Oderemi 2015). Section 49 states that -

1) Every person intending to vote shall present himself [sic] to a Presiding Officer at the polling unit in the constituency in which his name is registered with his voter's card.

2) The Presiding Officer shall, on being satisfied that the name of the person is on the Register of Voters, issue him a ballot paper, and indicate on the Register that the person has voted.

Section 52 stipulates that -

1) Voting at an election under this Act shall be by open secret ballot.

2) The use of electronic voting machine for the time being is prohibited.

3) A voter on receiving a ballot paper shall mark it in the manner prescribed by the Commission.

4) All ballots at an election under this Act at any polling station shall be deposited in the ballot box in the open view of the public.

In his contribution, Falana averred that the deployment of the card reader by INEC is not illegal. He submitted that INEC has the constitutional power to set the standards and guidelines for elections. In view of this, he argued that the card reader is part of accreditation rather than voting. He maintained that what the law proscribed is electronic voting and not card readers. Therefore, according to him the use of the card reader in the 2015 general elections is legal and legitimate (cited in Oderemi 2015).

A civil society called the Society for Advancement and Protection of Public Rights (SAPPR) (2015) in its submission argued that the deployment of card readers is illegal because it violates section 52 (1) of the Electoral Act, 2010 (as amended). SAPPR opined that the use of the card reader for screening voter cards, or which has the effect of preventing a registered voter from voting, is beyond the powers of INEC. As such, SAPPR maintained that by virtue of sections 77(2) and 117(2) of the 1999 Constitution of Nigeria (as amended), INEC had no power to deprive eligible Nigerians of the right to vote at the election (cited in Oderemi 2015).

Banire (2015) contended that electronic voting machines and card readers are two different devices that are not necessarily deployed together for all purposes. 
He explained that a card reader is not an electronic voting machine but a machine used for accreditation of voters only before the actual voting. According to Banire, electronic voting requires no ballot papers whereas the 2015 general election was ballot-paper-based. He argued that what section 52(2) prohibits (as indicated earlier) is the use of electronic voting machines but not the use of card reader for accreditation of voters. Banire (2015) therefore concluded that the use of card readers is not prohibited. In view of this, he argued, what is not prohibited is permitted in law. He cited the case of Ojo Bolarinwa Theophilous vs. Federal Republic of Nigeria (2012) LPELR-9846 (CA), wherein the Court of Appeal declared that 'The basic canon of interpretation or construction of statutory provisions remains that what is not expressly prohibited by a statute is impliedly permitted.'

Thus, since the use of card readers for the purpose of accreditation of voters is not prohibited by the Electoral Act, 2010 (as amended), according to Banire (2015) the card readers are definitely permitted. Furthermore, Banire maintained that accreditation of voters is not the same thing as casting of votes, because a person may be accredited without presenting him or herself to vote. The difference between accreditation and voting is underscored, according to Banire, by section 49(1) and (2) of the Electoral Act, 2010 (as amended). In order to separate accreditation from actual voting, he opined that the 2015 INEC Guidelines and Manual for Election Officials provides that accreditation shall be conducted between 8:00 a.m. and 13:00 p.m. or such time as the last person in the queue finishes; by contrast, voting commences at 13:30 p.m. or as soon thereafter as accreditation is completed, until the last voter concludes.

Citing section 52 of the Electoral Act, 2010 (as amended), Peters (2015) argued that the use of the card reader is illegal. Section 52 clearly stipulates that the use of electronic voting machines for the time being is prohibited. He maintained that INEC has in respect of the introduction of the card reader gone beyond its limits. Peters submitted that the card reader was only mentioned and introduced in the Electoral Manual 2015. In view of this, according to him, its use is illegal and void because the evergreen policy of the law is that where a statute provides a method of doing a particular thing, no other method would be accepted. He cited the case of Ajuta II v. Ngene (2002) 1 NWLR (Part 748) at page 300 paragraph C. In this case, C. Muhammad J.C.A. said

It has become trite that where a statute provides for the manner of doing a particular act, only that manner as provided by the enabling legislation would be acceptable. The doing of the act by a vehicle other than that provided by law for its attainment would be declared void.

To that extent, according to Peters (2015) every other requirement including the card reader outside the said section 49(1) and (2) of the Electoral Act that is 
contained in the Electoral Manual 2015 is illegal and void. He accused INEC of developing false confidence that it can do and undo under the cover of 'an umpire' instead of pursuing the amendment of the law to accommodate the new invention (card reader). He advised that the Electoral Act, 2010 (as amended) should be amended to include the card reader. Until this is done, he posited that the use of the card reader remains illegal.

Peters (2015) also observed a contradiction between the Electoral Act, 2010 (as amended) and the Electoral Manual 2015 wherein the card reader was introduced for the accreditation process of the 2015 general elections. According to him, section 49(1) of the Electoral Act, 2010 (as amended) stipulated that an intending voter shall mandatorily present to the Presiding Officer for accreditation processes. Contrarily, the Electoral Manual 2015 said the intending voter shall present to an Assistant Presiding Officer. Peters (2015) cited the Latin maxim 'expressio unius est exclusio alterius' - which means the express mention of a name or thing in a statute excludes the applicability of other things or names not specifically mentioned. To that extent the absence of the name of Assistant Presiding Officer in section 49(1) of the Electoral Act underscored the position of the Electoral Act, 2010 (as amended) that an Assistant Presiding Officer has nothing to do with the accreditation process in Nigeria's electoral system.

When the words used in a statute are clear, they must be given their natural and ordinary meaning. It is therefore clear that electronic voting - which the law prohibited in Nigeria - is not the same thing as a card reader. As such, the use of the card reader as part of the accreditation process in the 2015 general elections was in line with legal frameworks for the elections. In spite of the hullabaloo about the card reader, it was eventually used for the 2015 general election. However, the device had some challenges in its operation during the election.

\section{CHALLENGES OF THE SMART CARD READER IN THE 2015 ELECTIONS}

In spite of assurances given by INEC to address the issues raised by the pilot run using card readers in twelve states of the federation, the 2015 general elections witnessed an inability of the device to deliver effectively in a large number of polling units. This happened especially in the presidential and National Assembly elections.

What challenges were card readers confronted with in their operation for the purpose of accreditation in the 2015 general elections? First, the level of awareness among voters about the card reader was poor. A large number of Nigerians, especially the electorate in rural communities, were completely unaware of the device. Many of these people had neither seen nor heard about the card reader until election day. These voters had no information about the role of the card 
reader in the elections and there was a lot misconception about the device. To some of the electorate, the card reader seemed like a voting device. The inadequate dissemination of information and poor sensitisation of the electorate regarding the card reader led to some strained human relations, with resulting uncooperative attitudes between some illiterate voters and election officials.

Second, the training given to ad hoc and INEC staff on the use of the card reader was inadequate. Most Presiding Officers and Assistant President Officers in the polling units were not effectively trained in the proper use and handling of the card reader. In most cases the venues provided by INEC for training were crowded and not conducive to learning, such that most trainees did not receive proper instruction in the use of the card reader. There were imperfect practical demonstrations of how the card reader would be effective. In some cases, two card readers were provided for a class of a hundred trainees and many trainees did not have the opportunity to operate the device. In some cases, those who received training were replaced by people who had no proper knowledge of how to use the device effectively. All these issues led to poor handling of the card reader during the elections, to the extent that the protective film of some card readers was not removed, which resulted in the device being unable to detect thumbprints.

Card reader breakdown was also witnessed during the elections. Some devices malfunctioned on the day of the elections. Although INEC had provided back-ups in case of card reader breakdown, some of the back-ups also failed to function. For instance, five card readers were deployed for use at the polling unit of the presidential candidate of the PDP in Bayelsa State, yet none of them functioned. Similarly, the card reader at the polling unit of the vice-presidential candidate of APC was non-functional. A few card readers were unable to function owing to blank screens, non-activation of subscriber identification module (SIM) cards in the device, or flat batteries. Some INEC officials, according to Vanguard (2015), attributed the failure of card readers to INEC engineers who could not decode the inbuilt security installation in the devices. The security code in the card reader is reportedly designed to record the time and date of voting. One official claimed that the cards were initially programmed for 14 February and that with the postponement to 28 March, some card readers had not been reprogrammed (Vanguard 2015).

When the card readers did function, a few of the devices were confronted with the challenge of PVC authentication and biometric data verification of the voters in the polling units. The authentication and verification of card and voters respectively were components of the accreditation process for the election. A number of PVCs issued to voters by INEC could not be authenticated, thereby disenfranchising some eligible voters in the elections. Where voters' cards were authenticated, often their holders' biometric data could not be verified after several 
trials; and where it was verified, the devices worked slowly. For instance, in Borno State, $10 \%$ of eligible voters' cards were authenticated and biometric data was verified by card readers at most of the polling units (Odiakose 2015). However, the inability of the device to capture the fingerprints of voters was attributed to greasy or dirty fingers of the voters. Often people had to scrub their hands on the ground to ensure the device could read their fingerprints (Okoro 2015).

Following the widespread failure of the card readers, Prof. Jega changed the guidelines for the conduct of elections on $28 \mathrm{March}$, and approved the use of manual accreditation in areas that the smart card readers had malfunctioned during the presidential and National Assembly elections in the country (Odiakose 2015). These changes were made while the election was ongoing and after millions of frustrated voters had gone home disenchanted. The announcement by the INEC chairman seemed to have eased accreditation in many places. However, the extent to which this announcement may have inadvertently opened the door for electoral fraud is yet to be fully analysed (Amenaghawon 2015). It is unfortunate that the rules of the game were changed in the middle of the electoral competition. In spite of this, the smart card reader had an impact on the 2015 general elections.

\section{IMPACT OF SMART CARD READERS ON 2015 GENERAL ELECTIONS}

Despite the challenges that confronted the operation of some of the smart card readers during the 2015 general election, a significant effect of the device usage was observed after the elections. First, the use of the card reader increased and reinforced public confidence and trust in the electoral process. As already discussed, public confidence in each step of an election process is critical to the integrity of an election. Citizens not only have a right to participate in elections, they have a right to know for themselves whether the electoral process is valid (Open Election Data Initiative n.d.). Sadly, previous elections in Nigeria - particularly the 2007 general election - had made Nigerians completely lose confidence in the electoral process. Indeed, the flaws that characterised the conduct of the 2007 elections severely dented Nigeria's image and electoral integrity (Orji \& Uzodi 2012). The election fell short of basic international standards, to the extent that it was considered the worst in the history of electoral democracy in Nigeria.

In short, public confidence depends on the integrity of an election, and the 2015 general election appeared to possess this. The Nigeria Civil Society Situation Room (2015) described the 2015 elections as the most successful general elections in recent Nigerian history, and as such the elections renewed citizens' confidence in the electoral process. Indeed, most Nigerians after the elections believed that their votes would count and their will could be respected in future elections; this perception has reinforced the legitimacy of Nigeria's democratic process. 
Second, electoral fraud was reduced. Successive elections in Nigeria since the colonial period lacked the essential ingredients of democratic electoral process: transparency, fairness and freeness. Sadly, electoral fraud did not abate after independence. Indeed, since the inception of the Fourth Republic, a series of elections has been conducted with large-scale electoral fraud and malpractice. According to Ijim et al. (2011), the 2003 general elections effectively put Nigeria on the map of countries that do not understand or respect democracy. Ijim et al. argued that the monumental and state-sponsored structural rigging showed a country with no regard for people's votes. The 2011 general election, although described by international observers as free and fair, lacked credibility in its conduct - especially in the rural areas of Nigeria (Ijim et al. 2011).

The smart card reader checked the undemocratic attitude of politicians in polling-booth electoral malpractice. The Nigeria Civil Society Situation Room (2015) described the device as a game changer in the 2015 general elections. According to the Situation Room, the politicians and candidates were unfamiliar with and even afraid of the card readers, as they had not learnt how to manipulate them. This fact in itself limited their ability to rig the elections.

Third, election litigation was minimised. The total number of post-election litigation cases related to the general elections of 2003, 2007, 2011 and 2005 were 560, 1290, 731 and 297 respectively. These figures show that the 2015 elections incurred the least litigation during Nigeria's Fourth Republic. Indeed, there was a departure from the past where every election outcome was contested at the election tribunal. Most of the candidates that lost in the 2015 general election did not challenge the outcome. In fact, some of the strongest contenders who did not win in the election embraced and congratulated the winners. For instance, the PDP presidential candidate immediately congratulated the APC presidential candidate who had won the presidential election. This attitude was evident across many states of the federation during the governorship, State House of Assembly and National Assembly elections.

In addition, electoral conflict and violence was minimal as the election was seen to be transparent and credible owing to the use of the card reader. Elections in Nigeria since independence have been marred by violence. However, the 2011 postelection violence stands out in terms of its magnitude, severity and consequences (Orji \& Uzodi 2012). Indeed, the usually excessive and pointless attacking and degrading between the election winners and losers in past electoral contests were significantly reduced in the 2015 general elections. In view of the minimal level of electoral fraud owing to the use of the card reader, tensions were reduced among the political gladiators, and electoral conflict and violence was grossly diminished after the 2015 elections compared with past elections in Nigeria. 
Furthermore, Nigeria's democratic capacity has increased and its democratic institutions have been strengthened. Nigerians and Nigeria's democratic institutions now have the knowledge needed to hold a free and fair election in order to deepen the democratic process.

\section{SMART CARD READER AND FUTURE ELECTIONS: THE WAY FORWARD}

The introduction of information and communication technologies into the electoral process is generating both interest and concern among voters as well as practitioners across the globe. Today, most electoral management bodies around the world use new technologies with the aim of improving their electoral processes (ACE Project n.d.). However, the new software and devices, including smart card readers, must be deployed in a manner that leads to their effective use.

Without doubt, the smart card reader played a significant role in the 2015 general elections in Nigeria. However, there is a need to ensure that issues and challenges that arose through the use of the device around the time of the elections do not reoccur in future elections. A number of mechanisms need to be put in place by INEC for the deployment of the card reader in future elections so as to strengthen the democratic process. INEC should ensure that its conduct and activities in future elections are transparent, especially with the use of technology like the card reader. Transparency is a key principle in credible elections and this will bring about trust and public confidence in the electoral process. Also, INEC should consult widely and carry out effective campaigns about the card reader and any other technology to be deployed in future elections. Stakeholders - including the media, political parties, civil societies, the National Assembly and the electorate - should be adequately consulted. INEC should partner with them to carry out mass dissemination of information and to sensitise people about the need for technology to improve the electoral process and to deepen democracy. INEC should endeavour to manage information about the technology and changes so that stakeholders do not have unrealistic expectations and do not impose impossible deadlines (ACE Project n.d.).

The need to strengthen electoral laws on conformity for technology used in future elections is germane. The Electoral Act, 2010 (as amended) should be further amended to include the use of the card reader for biometric verification of voters, for the purpose of accreditation. The National Assembly should be approached by INEC as soon as possible to amend the electoral legal frameworks regarding the use of card readers, in order to address the issue of legality which the card reader generated in 2015. Furthermore, adequate training of election officials and temporary and permanent staff of INEC should be conducted in a 
suitable environment well ahead of future elections, so as to give room for practical demonstrations on how to use the device effectively. Enough card readers should be made available during the training session. Every trainee should undergo a mock test during their training, and strict compliance with all instructions given to trainees should be monitored. The trainees' allowances should be paid in full to motivate them to handle the device properly.

In addition, INEC must regularly update and re-examine the relevance of the card reader to future elections in Nigeria. Technology is not static, and the level of technological change is so rapid that a device used five years ago may not be relevant today. To conduct a credible, transparent, free and fair election in the future, with the use of the card reader, INEC must invest in regular staff training and development to remain up to date with modern technological changes. These developments are fast occupying the democratic landscape and electoral process. Consequently, future general elections in Nigeria should gradually become more technologically driven.

\section{CONCLUSION}

The use of card readers generated debate at the time of the 2015 general elections. However, despite the challenges of using the device it also had a significant and positive impact on the election and its outcome. These influences are not easy to quantify. INEC's aim in deploying the card reader was to improve the electoral process and deepen the democratic process. Unfortunately a lack of trust and the occurrence of suspicion and altercations among stakeholders with vested interests in the election created tension within the polity. With the use of the card reader in the 2015 general elections, and the gradual deployment of technology in subsequent elections in Nigeria, the prospect of the country becoming one in which elections are largely managed through technology appears to be achievable.

\section{- REFERENCES}

ACE Project n.d., 'Elections and technology', The Electoral Knowledge Network, viewed 16 June 2015, http:/ / aceproject.org/ace-en/topics/et/ et10

Adichie, C 2015, 'Chimamanda Adichie: postponed election, an act of desperation from an incumbent terrified of losing', viewed 15 June 2015, http:/ / dailypost. $\mathrm{ng} / 2015 / 02 / 11 /$ chimamanda-adichie-postponed-election-act-desperationincumbent-terrified-losing/

Alvarez, M \& Hall, E 2008, 'Electronic elections: the perils and promises of digital democracy', Princeton University Press, Princeton. 
Amenaghawon, J 2015, '2015 Nigeria elections: the gains, the challenges and the lessons', Premium Times online, viewed 20 June 2015, http://opinion. premiumtimesng.com / 2015/04/24/2015-nigeria-elections-the-gains-thechallenges-and-the-lessons-by-joseph-amenaghawon/

Banire, M 2015, 'Card reader and the electoral act - any conflict?' viewed 14 June 2015 http:// thenationonlineng.net/ new/ card-reader-and-the-electoral-act-anyconflict/

Dunne, S 2006, 'Elections and security', viewed 5 June 2015, http:/ / engineer-ng.net/ profiles/blogs/gains-of-the-inec-card-reader-in-the-2015-elections

Ebhomele, E 2015, 'Jega: the real Nigerian hero', The News online, viewed 9 June 2015, http:/ / thenewsnigeria.com.ng/2015/04/13/jega-the-real-nigerian-hero/

Engineering Network Team 2015, 'Gains of the INEC card reader in the 2015 elections', The Engineering Network online, viewed 7 June 2015, http:// engineer-ng.net / profiles / blogs / gains-of-the-inec-card-reader-in-the-2015elections

Gelb, A \& Decker, C 2012, 'Cash at your fingertips: biometric technology for transfers in developing countries', Review of Policy Research, vol. 29, no. 1, pp. 91-117.

Ijim, AU, James, A \& Anyabe, J 2011, 'Elections and letting the votes count in Nigeria: implications for democratic stability in an emerging third world society', African Journal of Social Sciences, vol. 1 no. 3, pp. 92-106.

INEC 2015, Independent National Electoral Commission: 'Frequently asked questions', viewed 10 June 2015, http:/ / www.inecnigeria.org/?page_id=28

International Foundation for Electoral Systems 2015, 'Protecting the vote: election security worldwide', viewed 18 June 2015, http:/ / www.ifes.org/multimedia/ protecting-vote-election-security-worldwide

International Foundation for Electoral Systems 2015, 'A look at Nigeria's 2015 general elections', viewed 17 June 2015, http://www.ifes.org/multimedia/ look-nigerias-2015-general-elections

International Republican Institute 2015, 'Nigerian voters demonstrate commitment to process, election day logistics need improvement', viewed 12 June 2015, http:/ / www.iri.org/resource/nigerian-voters-demonstrate-commitment-processelection-day-logistics-need-improvement

Jega, A 2014, 'Challenges of fraud-free elections under a democratic dispensation', paper presented at the Mustapha Akanbi Foundation Public Lecture, March 12, viewed 14 June 2015, http:/ / www.mafng.org/documents/jega_challenges_ of_fraud_free_election_under_democracy.pdf

Jinadu, LA 2005, 'Political science, elections and democratic transitions: fragments of an autobiography and some conjectures' in G Onu \& A Momoh (eds), Elections and democratic consolidation in Nigeria, National Association of Political Science, Lagos. 
Kendhammer, B 2015, 'Boko Haram and Nigeria's 2015 elections: a fighting chance for democracy?', viewed 17 June 2015, https://africaplus.wordpress. com/2015/03/16/boko-haram-and-nigerias-2015-elections-a-fightingchance-for-democracy/

López-Pintor, R 2010, 'Assessing electoral fraud in new democracies: a basic conceptual framework', International Foundation for Electoral Systems (IFES) Electoral Fraud White Paper Series, viewed 17 June 2015 https: / www. ifes.org/sites / default/files/rlp_electoral_fraud_white_paper_web.pdf

Momodu, D 2015, 'Saraki and the battle for 2019', Nigerian Bulletin online, viewed 18 June 2015, https:/ / www.nigerianbulletin.com/threads/ saraki-and-the-battlefor-2019-dele-momodu.113063/

Nigeria Civil Society Situation Room 2015, Report on Nigeria's 2015 general elections, viewed 15 June 2015, http:/ /www.placng.org/situation_room/sr/wp-content/ uploads / 2015/07/SITUATION-ROOM-REPORT-ON-2015-ELECTIONS.pdf

Nnoli, O 1990, 'The 1987 local government elections in the eastern zone of Nigeria: Plateau, Benue, Anambra, Imo, Rivers, Cross River and Akwa Ibom states', in L Jinadu, A \& T Edoh (eds), The 1987-1988 local government elections in Nigeria, vol.1 no. 1 Case Studies, National Electoral Commission, Lagos.

Oderemi, K 2015, 'Card readers: to be or not to be?'Latest Nigerian News, viewed 20 June 2015, http:/ / www.latestnigeriannews.com/news/1261223/card-readerof-controversy.html.

Odiakose, M 2015, 'INEC and use of card readers', Nigerian Pilot, viewed 24 June, http:/ / nigerianpilot.com/inec-and-use-of-card-readers/

Okolie, AM 2005, 'Electoral fraud and the future of elections in Nigeria: 19992003', in G Onu \& A Momoh (eds), Elections and democratic consolidation in Nigeria, National Association of Political Science, Lagos.

Okoro, E 2015, 'Card reader: clash of technology and politics', Latest Nigerian News, viewed 24 June 2015, http://www.latestnigeriannews.com/news/1272029/ card-reader-clash-of-technology-and-politics.html

Omotola, JS 2013, ‘Trapped in Transition: Nigeria's First Democratic Decade and Beyond', Taiwan Journal of Democracy, vol. 9, no. 2. pp. 171-200.

Orji, N \& Uzodi, N 2012, Post election violence in Nigeria: experience with the 2011 elections, Policy and Legal Advocacy Centre, Abuja.

Peters, SC 2015, 'Opinion: illegality or otherwise of card readers in Nigerian electoral jurisprudence', The Will, viewed 18 June 2015, http: / thewillnigeria. $\mathrm{com} /$ news/ opinion-illegality-or-otherwise-of-card-readers-in-nigerian-electoraljurisprudence/

Piccolino, G 2015, 'What other African elections tell us about Nigeria's bet on biometrics', Washington Post, viewed 18 June 2015, www.washingtonpost. com/blogs/monkey-cage/wp/2015/03/10/ what-other-african-elections-tell-usabout-nigerias-bet-on-biometrics/ 
Policy and Legal Advocacy Centre 2015a, 'Concerns over postponement of the general elections', Legist, viewed 20 June 2015, http://placng.org/legist/ concerns-over-postponement-of-the-general-elections/

Policy and Legal Advocacy Centre 2015b, 'The constitutionality or not of the use of card readers in the 2015 elections in Nigeria', Legist, viewed 10 June 2015, http:/ / placng.org/ legist/ the-constitutionality-or-not-of-the-use-of-card-readersin-the-2015-elections-in-nigeria/

Premium Times 2015, 'Armed forces have no role in Nigeria's elections, Falana tells Jega', viewed 15 June 2015, http://www.premiumtimesng.com/news/ top-news / 177158-armed-forces-have-no-role-in-nigerias-elections-falana-tells-jega. html

The Electoral Institute 2014, 'Frequently asked questions', viewed 18 June 2015, http: / / www.inecnigeria.org / ?page_id=28

Vanguard 2015, 'After initial card reader failure: Nigerians persevere, vote in peaceful elections', Vanguard online, viewed 21 June 2015,

http: / / www.vanguardngr.com/2015/03/after-initial-card-reader-failurenigerians-persevere-vote-in-peaceful-elections/ 